\title{
Coordination of the Eurasian Economic Union and the Silk Road Economic Belt: Opportunities for Russia1, 2
}

\author{
I. Makarov, A. Sokolova
}

Igor Makarov - PhD, Associate Professor, Department of Global Economy, National Research University Higher School of Economics, 20 Myasnitskaya, 101000 Moscow, Russia; E-mail: imakarov@hse.ru

Anna Sokolova - Junior Research Fellow, Center for Comprehensive European and International Studies, National Research University Higher School of Economics, 20 Myasnitskaya, 101000 Moscow, Russia; E-mail: aksokolova@hse.ru

This article examines the opportunities created for Russia by the launch of China's Silk Road Economic Belt (SREB). On one level, the SREB is a transport and logistics initiative to deliver Chinese goods to Europe. However, more than this, the SREB is a comprehensive project to develop Central Asian countries and to respond to economic and political processes within China and the larger Asia-Pacific region. Specifically, the SREB is intended to meet challenges increasing income gaps, the growing presence of the United States in Asia and changing labour patterns - that are transforming the region's social and economic landscape.

In this context, the SREB is an expression of China's desire to create strong regional value chains, to outsource labour-intensive and environmentally harmful production, to foster the development of northwestern China, to create conditions for political stability in the Xinjiang Uyghur Autonomous Region, and to guarantee that Chinese construction firms are operating at full capacity. To the extent that the SREB is about the transport of goods, this is driven by the need to diversify export risks in the face of deteriorating military and political conditions in the sea rather than by perceived commercial benefits.

The Joint Statement on Cooperation on the Construction of Joint Eurasian Economic Union and the Silk Road Projects signed on 8 May 2015 represents a milestone in China-Russia relations and potentially lays to rest concerns about competition between these two projects. Indeed, the Eurasian Economic Union (EEU) and the SREB are complementary projects with the former providing an institutional basis for cooperation and the latter providing the necessary investment resources for joint projects. If successful, the coordination of the EEU and the SREB will make it possible to overcome potential contradictions in Central Asia - the source of the most serious tensions between Russia and China.

Participation in the SREB may come with certain benefits for Russia. First, the integration of Russia's transportation system into the logistics network of the Eurasian region will give Russia's transit and associated logistical services access to growing regional markets. Second, the SREB creates opportunities to strengthen industrial cooperation between neighbouring countries and to develop new economic clusters. Third, the integration of the EEU and the SREB may support the more ambitious project of cooperation in the greater Eurasia area and transform the region into a new centre of economic development on the global level.

Key words: Eurasian Economic Union; Silk Road Economic Belt; Russia-China relations

\section{The Silk Road Economic Belt as a Part of the One Belt One Road Initiative}

China's plans for the Silk Road Economic Belt (SREB) were announced in September 2013 when, during a visit to Astana, Chinese president Xi Jinping expressed a desire "to forge closer

${ }^{1}$ The article was submitted to the editors in February 2016.

${ }^{2}$ This research was funded by the Basic Research Program at the National Research University Higher School of Economics. 
economic ties, deepen cooperation and expand development space in the Eurasian region" [Ministry of Foreign Affairs of the People's Republic of China, 2013]. The proposed corridor along the Silk Road differed from traditional models of regional cooperation in that it did not imply the creation of a supranational governing structure. In November 2014, Xi announced that China would provide $\$ 40$ billion to the Silk Road Fund in order to finance the construction and modernization of roads, railroads and pipelines with the goal of increasing the volume of trade with Europe. Later, the land-based SREB was integrated into the One Belt One Road (OBOR) initiative in the Indian Ocean. The concept of the Maritime Silk Road (MSR) had been in the air since 2014 with the establishment of a private capital company, the Maritime Silk Road Investment Fund Management Center, to set up a bank with $\$ 100$ billion in assets to be invested in the development of shipping routes [Bondaz, Godement, Kratz et al., 2015]. The MSR is a logical continuation of Chinese investments in key ports in the Indian Ocean and around the world during the last decade, unofficially known as "string of pearls" [Makarov, Makarova, Karaganov et al., 2016].

The linkage of the SREB and the MSR through the OBOR represents a full-scale transformation of the logistics network of Eurasia, including South East Asia, Mongolia and the Russian Primorye, and may perhaps even fuel the development of the Northern Sea Route. Furthermore, the OBOR has become a comprehensive strategy and key element of Chinese foreign policy. The importance of this initiative for the country is illustrated by the fact that the development plans of nearly all ministries and governmental bodies were reoriented toward the development of the OBOR [Bondaz, Godement, Kratz et al., 2015].

The first official statement of the comprehensive vision of the OBOR was the Vision and Actions on Jointly Building Silk Road Economic Belt and 21st-Century Maritime Silk Road document released on 28 March 2015, even though it is only vaguely defined and the geographical scope is not precisely delimited. The SREB focuses on connecting China to Central Asia, Russia and Europe, and also to the Persian Gulf and Mediterranean countries. The MSR has two prospective routes - one connecting China to Europe across the South China Sea and the Indian Ocean and the other connecting the South China Sea to the southern part of the Pacific Ocean [National Development and Reform Commission (NDRC), 2015].

The document confirms that the OBOR is open to all countries as well as international and regional organizations, and establishes a foundation for economic cooperation between China and all interested partners. According to Xi Jinping, this is "not a solo for China, but a symphony performed by all the countries involved." [Xi, 2015] China is ready to work with other countries on the development of the initiative, supplementing it with new projects, using cooperative multilateral institutions and also encouraging equal negotiations on international issues [NDRC, 2015]. Relevant institutions include the Shanghai Cooperation Organisation (SCO), the Association of Southeast Nations Plus China (ASEAN+1), the Asia-Pacific Economic Cooperation, the Asia-Europe Meeting, the Asia Cooperation Dialogue, Economic Cooperation and Central Asia Regional Economic Cooperation (CAREC), and the Conference on Interaction and Confidence-Building Measures in Asia. The official commitment to a multilateral foundation for the OBOR is further demonstrated by the frequency of official visits by Xi Jinping - since the beginning of his presidency in 2013, he has visited Russia, India, Pakistan, Iran, Kazakhstan, the Kyrgyz Republic, the Tajik Republic, Belarus, Vietnam, Singapore, Korea, Indonesia, Egypt and Saudi Arabia among others.

Between late 2015 and early 2016, several international documents were signed within the framework of the OBOR. The most significant of these was the Joint Statement on Cooperation on the Construction of Joint Eurasian Economic Union and the Silk Road Projects, signed on 8 May 2015. In June 2015 a joint Russia-China working group defined the key areas 
for cooperation as being major infrastructure projects, the creation of a system for the protection of mutual investments, promotion of investments and the creation of mechanisms for the resolution of investment disputes. Additional long-term priorities for cooperation include the development of the high-tech industry, medical and educational services and scientific research [Ministry of Economic Development of the Russian Federation, 2015]. In the same month, summits of the SCO and the BRICS grouping of Brazil, Russia, India, China and South Africa were held in Ufa and included informal meetings between the heads of state of the major OBOR stakeholders.

In November 2015, China signed an agreement with Pakistan to rent a deep-water port in Gwadar (near the border with Iran) for 40 years. Because maritime and land infrastructure can be jointly developed in this case, Gwadar is expected to emerge as a major transportation hub for Chinese industrial production and natural resources intended for the Chinese market [Ministry of Foreign Affairs, 2015a]. At the same time, it will be the end point of the China-Pakistan Economic Corridor (CPEC). In particular, the railway linking Kashgar (in the Xinjiang Uyghur Autonomous region in Western China) to Gwadar should reduce the travel time from China to Pakistan from 12 days to 36 hours.

Not all states support China's initiative. India is wary of the MSR due to concerns that it could strengthen China's influence in the Indian Ocean. India also opposes the construction of the CPEC because of its impact on the disputed region of Kashmir. The development of the MSR directly touches upon the interests of the ASEAN countries. And in Russia, many consider the SREB to be a vehicle for Chinese expansion into Central Asia. In western countries this project is compared with the Marshall plan in which a powerful state is able to use its economic strength to resolve foreign policy issues [Habova, 2015].

China denies that the OBOR will fuel conflict, stressing that the megaproject is "an open and inclusive initiative for regional cooperation" [Ministry of Foreign Affairs, 2015b]. The purely commercial nature of the initiative is strongly emphasized. However, experts and some Chinese officials have suggested that the OBOR is driven by other, non-commercial, considerations [Denisov, 2015]. For example, Qiao Liang, a major general in the People's Liberation Army of China, characterizes the OBOR as a response strategy to the "pivot to Asia" by the U.S. (cited in [Sisci, 2015]). Zhao Zhouxian and Liu Guangming, experts at the National Defense University, suggest further that the SREB “expands the strategic security space around China, stabilizes energy supplies, ensures economic security, and breaks through the enveloping containment strategy" [Denisov, 2015]. Zhang Yunling points to potential tensions as a result, stating that this initiative "corresponds to the main trend of the era of peace, cooperation and mutual benefit" while noting that "other countries in the region are still not quite prepared for this psychologically" [Chen, 2015]. If Zhang Yunling, president of the China Society of AsiaPacific, is correct in his assessment that the concept "reflects the international strategic thinking of the new leader of China," then the OBOR represents a departure from the characteristic disinterest in foreign expansion by China's leaders who, even after China's rapid economic growth and increasing prominence in global affairs in the last quarter of the 20th century, continued to abide by the principle formulated by Deng Xiaoping: "hide your strength, bide your time" [Chen, 2015; Denisov, 2015].

Either way, the effects of the OBOR will not be felt overnight. The initiative involves countries accounting for about $55 \%$ of global gross domestic product, about $70 \%$ of the world's population and $75 \%$ of proven energy reserves [World Economic Forum, 2015]. Given this, it is not surprising that a study conducted by Renmin University of China predicts it will take about 35 years to complete the planned projects - a timeline that corresponds with the 100-year anniversary of the founding of the People's Republic of China in 2049 [Bondaz, Godement, Kratz 
et al., 2015]. This period is sometimes referred to as the new 30 years, marking a break with ruling periods by Mao Zedong and Deng Xiaoping [Bondaz, Godement, Kratz et al., 2015].

\section{Mechanisms to Fund the OBOR}

There are several key institutions in the Asia-Pacific region that finance projects in the field of transport infrastructure: the Silk Road Fund, the Asian Infrastructure Investment Bank (AIIB), the New Development Bank (NDB) and the Asian Development Bank (ADB). Each of these institutions was either established by China or operates with its participation and could play a significant role in the development of the OBOR.

China established the Silk Road Fund in early 2015 and it has an authorized capital of $\$ 40$ billion. Initially, it was assumed that the fund would specialize in transport and logistics projects; however, its scope has become much wider. In April 2015, it made its first investment in the amount of $\$ 1.65$ billion in the construction of a power plant in Pakistan as a part of the development of the CPEC. The second investment was the acquisition of Pirelli, the Italian tire producer, by the China National Chemical Corporation in June 2015 [Silk Road Fund, 2015].

In September 2015, the Silk Road Fund signed a framework agreement with Russia's NOVATEK and received a 9.9\% share in Yamal LNG, an ambitious project in Russia to construct a plant on the South Tambey (Yuzhno-Tambeyskoye) gas field. The total cost of the project is $\$ 27$ billion, and includes three production lines of 5.5 million tons of liquefied natural gas annually. Other shareholders in the project are NOVATEK (which owns $50 \%+1$ share), the French company Total (20\%) and the Chinese company CNPC (20\%) [NOVATEK, 2015].

The Russian Direct Investment Fund (RDIF), the Bank for Development and Foreign Economic Affairs (Vnesheconombank, or VEB) and the Silk Road Fund signed an agreement to cooperatively explore investment opportunities in Russian and Chinese priority economic areas, including transport and petrochemicals [RDIF, 2015].

According to Chinese media reports, in early September 2015 the Silk Road Fund's management visited Tajikistan to inspect a cotton-processing factory under construction in the Dangara. As a part of the project, a Tajik-Chinese joint venture, Zhongtai-Khatlon-Xin-Xilu, will rent 15,000 hectares in four districts of the Khatlon region in southern Tajikistan to cultivate cotton for a period of 49 years.

The AIIB was established on 29 June 2015 through a Chinese initiative with an authorized capital of $\$ 100$ billion. According to Xi Jinping, the AIIB "will provide an impetus for economic growth in Asia and the rest of world" [China Daily USA, 2016]. Its primary goal is to "channel more resources, particularly private investment, into infrastructure projects" in Asia.

Currently, 57 countries participate in the AIIB [AIIB, 2015a]. China holds the largest share ( $26.06 \%$, equivalent to $\$ 29.78$ billion) of its authorized capital and has veto power. India is the second-largest shareholder $(7.51 \%)$, followed by Russia (5.92\% equivalent to $\$ 6.54$ billion) [AIIB, 2015b]. In January 2016, Alexey Ulyukaev, Russia's minister of economic development, was appointed to represent Russia on the AIIB board of governors (Ministry of Economic Development, 2016). Russia's participation in the AIIB makes it possible to raise funds for the development of domestic infrastructure projects, and Russia is currently preparing proposals [Ulyukaev, 2016].

The NDB was launched on 21 July 2015 in order to fund energy and infrastructure projects in BRICS countries. The selection of initial projects is planned for 2016.

The oldest regional development institution participating in OBOR initiatives is the ADB, founded in 1966. It finances projects in the fields of agriculture, natural resources, education, health, energy and finance. In 2014, the ADB allocated approximately \$23 billion in the form 
of loans and grants to various areas including Central Asia, where the ADB is implementing a number of initiatives under the CAREC [ADB, 2015]. All ten CAREC countries are members of the ADB. Since 1996, the ADB has invested $\$ 24.6$ billion in 158 projects in CAREC countries.

The ADB is less engaged in OBOR initiatives than other regional development institutions in large part because China's involvement in the ADB is minimal, whereas Japan's is significant. For this reason, although the ADB funds some projects in Central Asia, it adopts a neutral stance toward the OBOR at best.

Russia expects that these institutions will be able to provide funding for a range of projects in Russia, primarily in the field of transport - for example, the high-speed Moscow-Kazan railway and its possible extension to Yekaterinburg and further through Astana to Beijing, and also the Western China-Western Europe motorway with Kazan and St. Petersburg. There is also a high probability of multilateral financing for hydropower and renewable energy projects in the Russian Far East and Siberia.

\section{The Silk Road Economic Belt as a Transit Route}

In Russia, the SREB is perceived as a transit corridor for the movement of Chinese goods to Europe. Thus, discussion of the initiative focuses on a comparison of routes, some of which pass through Russia while others bypass the southern Russian border.

The Russian route follows the Trans-Siberian railroad, connecting China with Russia in Primorsky Krai. Freight included, the shipping cost from Shanghai to Brest by railway is about $\$ 2,200$ per 20 foot equivalent unit (TEU) [Valdai Discussion Club, 2015]. Because this route already operates at capacity, plans are underway to increase capacity by modernizing the BaikalAmur Mainline (BAM) and Trans-Siberian railways. The necessary investment is significant (562 billion rubles) but it is expected that export traffic will increase along a modernized TransSiberian railway [Makarov, Makarova, Karaganov et al., 2016]. The use of the Trans-Siberian railway as an export channel will inevitably compete with the transit development.

A second option is to transport Chinese goods to Russia through Kazakhstan. The connection with Russia is possible through Western Siberia by way of Urumqi to Omsk to Moscow to the European Union. The shipping cost from western China by this route is about $\$ 1,300$ per TEU. Most existing route segments operate at only $20 \%$ of their capacity, and it would require a significant investment to attract traffic currently using the West Siberian railway - this relatively small section of the Trans-Siberian railway transports more than $20 \%$ of total railway freight in the country [Russian Railways, 2016].

Currently, it is only possible to enter Russia from Kazakhstan in the Orenburg region. There are about 30 regular routes for container trains. Since 2011, regular container train shipments of Hewlett-Packard monitors and laptops have used a route from Chongqing, China, to Duisburg, Germany, and a train has travelled from Chengdu, China, to Lodz, Poland, once a week since 2012. However, in order to increase the use of this route a large investment to improve infrastructure would be necessary [Makarov et al., 2016].

In October 2014, Chinese investors expressed interest in the construction of a high-speed railway from Moscow to Kazan on the condition that the rail line would be later expanded to Beijing. A memorandum of understanding has been signed. The original plan was that the rail line between Moscow and Beijing would pass through Yekaterinburg, Astana, Irkutsk, UlanBator and Khabarovsk. Later, it was announced that from Astana the line would instead go through the Xinjiang Uygur Autonomous Region into Chinese territory, cutting travel time between Moscow and Beijing from six to two days. The approximate cost of this project will be 
$\$ 245$ billion. Although some important details (including the track gauge and the nature of the involvement of Chinese contractors) are still under negotiation, the opening of the route is scheduled for 2020. It is expected that the high-speed Moscow-Kazan railway will enhance EEU-SREB coordination "to become a model project for Russian-Chinese cooperation transport and infrastructure" [Putin, 2015].

A third option for moving goods from China to Europe bypasses Russia altogether. A route through Kazakhstan and Iran would the least expensive, with shipping costs of about $\$ 1,700$ TEU, but this would require an investment of approximately $\$ 2$ billion. An alternative is to ship cargo from the Kazakh port of Aktau across the Caspian Sea to Baku, then to Poti and finally to the Black Sea in Constanta, but this is the most expensive, up to $\$ 5,000$ per TEU. However, with large-scale investment ( $\$ 8$ billion) in container port facilities in Baku and Poti, reconstruction of roads, and the construction of tunnels and container logistical centres, the cost of transportation would decrease to $\$ 1,500$ per TEU [Valdai Discussion Club, 2015]. The route from Baku could also go to Kars (via Nakhichevan or Tbilisi) and then through Istanbul by railway to Europe - a route very similar to the International Transport Corridor EuropeCaucasus-Asia project initiated by the European Union in 1993, but never properly developed due to lack of funding. The development of the route through Turkey will, however, require even more investment [Biriucov, 2014].

These routes present alternatives to the traditional ocean shipping routes from China to Europe through the Malacca Strait and the Suez Canal. However, the disadvantage of the land routes is their higher cost - ships can carry more than 10,000 containers per voyage compared to 500 containers per train [Makarov, Makarova, Karaganov et al., 2016]. Consequently, huge economies of scale are achieved by shipping goods by sea. It is difficult to imagine that shipping costs between China and Europe by land could come close to the average cost of transportation by sea from Shanghai to Europe, which in early 2016 amounted to $\$ 932$ per TEU [Shanghai Shipping Exchange, 2016]. For this reason it is not surprising that land routes (mainly through Kazakhstan into Russia in the Orenburg region) account for less than $1 \%$ of the total cargo between China and Europe.

It is unlikely that share will increase significantly in the future, especially given that the growth of trade between China and Europe continues to slow. Between 2005 and 2011 the average annual growth rate was $22.5 \%$; however, after 2011, even taking into account growth of $10 \%$ in 2014 it decreased to 2.8\% [United Nations Statistics Division, 2015]. China is experiencing an economic slowdown and economic growth in the EU has not yet stabilized after the economic and financial crisis. Furthermore, by the end of 2015 the capacity of the global merchant fleet increased by about $7 \%$, which will lead to further decreases in tariffs on traditional maritime routes. At the same time there is a widening gap between supply and demand for transportation - the latter grew by only $1.5-2 \%$ despite low oil prices, pushing tariffs down even further [Paris, 2015]. In this context, land routes simply cannot compete.

Given this, it is important to consider the presence of non-economic factors pushing the development of land transit. In particular, the increased U.S. military presence in the Indian Ocean and the Asia-Pacific region, escalating political tension in the South China Sea, the bandwidth limitations of the Suez Canal, and the absence of an alternative to the Malacca Strait, have together meant that Chinese exports have become dangerously dependent on Singapore [Qu and Meng, 2012]. China therefore has a keen desire to diversify its export flows and the SREB and OBOR should be understood in this context. While the SREB certainly has a function as a transit corridor, it is a mistake to see this as its only function as is often the case in the Russian media and expert community. China's primary objective in developing the SREB is not transit. 


\section{Silk Road Economic Belt as a Development Belt}

The Russian vision of the SREB as a transit route is based on historical and cultural traditions. Russia is accustomed to seeing itself as a bridge between Europe and Asia, which is why Europe-Asia cooperation is a primary focus within the SREB.

The Silk Road as a metaphor for trade routes between China and Europe was introduced by the German historian Ferdinand von Richthofen in 1877 and remains deeply rooted in the European historical tradition [Vorob'ev, 2014]. This beautiful metaphor suggests a stable transport and transit route between China and Europe and lends itself easily to the Russian understanding of the SREB. However, the Silk Road has never been a single transit route. Mercantile operations were conducted through networks of trade routes in many towns, and there were almost no shipments or tradespeople moving all the way from one end to the other. One exception was Marco Polo and it was for this reason that he became well known.

The Chinese understanding of the Silk Road is quite different. Historically, the passage of goods from China to the West was limited to the territories of modern Afghanistan and Uzbekistan. During medieval times, trade - mostly with Arab merchants - barely extended beyond the borders of Chinese Xi'an. This informs the Chinese perspective of the SREB not as a transit route but as a geographical zone that includes a number of wealthy countries that trade intensely with each other. The word "belt" rather than "road" is the key to understanding the objectives of the new Chinese initiative.

Thus, the launch of the SREB is not an attempt to reduce transport costs between China and Europe. Rather, it is a response to the deep economic and political changes that are occurring in China and the entire Asia-Pacific region.

First, a structural transformation of China's social and economic model is now taking place, marked by a shifting emphasis away from expanding export-oriented production facilities in favour of developing domestic consumption and the services sector. This transformation has encountered difficulties and economic growth rates have been decreasing since 2011. Large infrastructure projects connecting the western Chinese provinces with Central Asia are a potential source of much-needed growth.

Second, China is transitioning from its role as the world's factory into that of a large consumer. At the same time, the divergence of incomes within the Asia-Pacific region is deepening an intraregional division of labour. New regional value chains have emerged in which China dominates. Meanwhile, labour-intensive, environmentally unfriendly and energy-intensive industries are being relocated from China to other countries in the region - initially to Bangladesh, Southeast Asian low-income countries, Mongolia, and now also to Central Asia. The whole of Asia is steadily reorienting itself away from an "Asia for the world" model to an "Asia for Asia” model [Bordachev, Likhacheva and Zhang, 2014].

Third, the division of labour within China itself is transforming. The highest growth rates are found in relatively poor central and western provinces as labour-intensive industries relocate to these regions, and opportunities for extensive economic growth still exist. This tendency is supported by officials who are interested in erasing regional disparities. Infrastructure projects and strengthened cooperation with Central Asia contribute to this goal.

Fourth, slowing economic growth rates aggravate the problem of instability in Xinjiang Uyghur Autonomous Region in the northwest of China. Uyghurs, a Muslim Turkic ethnic group, constitute about $45 \%$ of this region's population. Their conflict with the Chinese is rooted in a thousand years of history and Uyghur separatism has become one of the major domestic policy challenges facing China over the past decade. Accelerated development in the Xinjiang Uyghur 
Autonomous Region and strengthened economic ties with other Chinese provinces and neighbouring Muslim countries is one of the possible remedies to the problem.

Fifth, infrastructure development and vigorous real estate construction in China led to the emergence of a giant construction industry that provides jobs to tens of millions of people. However, with the largest projects in the east of China completed and the collapse of the real estate bubble in 2014, Chinese construction companies are looking beyond the domestic market for continued growth. Transport projects in Central Asia, and especially full-scale transit roads to Europe, present an ideal opportunity [Gabuev, 2015].

Taken together, these factors suggest that the development of transit for its own sake is hardly a primary objective of the SREB. Nevertheless, this does not mean that the transit routes to Europe will not be built. On the contrary, as the cost of shipment from China to Europe is not a key calculation, several trans-Eurasian roads could be opened within the SREB provided they comply with Chinese interests. Paramount among these interests is the emergence of Central Asia as a new centre for economic activity to host production facilities transferred from China, facilitate access to the natural resources of the region, accelerate the development of the north-western provinces and offer jobs to Chinese building contractors.

\section{The SREB and the EEU: Competition or Partnership?}

Russia's expert community intitially viewed China's ambitious plans to develop the SREB with caution for fear that the SREB would compete with the EEU [Fedorenko, 2013; Shajmergenov, 2015; Larin, 2015]. Such concerns were overblown, however, because the SREB and EEU operate according to different logics - in particular, the SREB does not imply any institutionalization.

This perception reflected a sense of disappointment among political elites and some experts that Russia is losing its position in Central Asia, ceding its status as a key player in the region to China. From 2000 to 2013, merchandise turnover between China and five Central Asian countries - Kazakhstan, Kyrgyzstan, Tajikistan, Turkmenistan and Uzbekistan - increased, according to the International Monetary Fund, from $\$ 1.8$ billion to $\$ 50$ billion before declining slightly to $\$ 45.1$ billion with a fall in raw material prices [International Monetary Fund, 2015]. It is a matter of some concern that this exceeded the turnover between these same countries and Russia, which was estimated to be $\$ 35$ billion and \$29 billion in 2013 and 2014 respectively [Russian Federation Federal State Statistics Service, 2016].

According to European Commission estimates, in 2013 China was the major trade partner of Kyrgyzstan (47.6\% of the republic's total merchandise turnover), Tajikistan (26.9\%), Turkmenistan (42.7\%) and Uzbekistan (22.5\%). Russia was the second to China in trade with Kyrgyzstan (19.7\%) and Uzbekistan (20.6\%), third for Kazakhstan (21.1\%), and fourth for Tajikistan (10.4\%) and Turkmenistan (7.8\%) [Fattibene, 2015].

China has not only significantly increased the volume of its trade with Central Asian republics but also continues to carry out investments in the region. In 2015, China decided to provide Kazakhstan with a $\$ 30$ billion investment package; Uzbekistan received $\$ 15$ billion and Kyrgyzstan received $\$ 3$ billion. These investments vastly exceed Russian investments of roughly $\$ 15$ billion in Central Asia in 2013-14. On the whole, Russia's investment potential cannot meet that of China [Zadorozhnyy, 2016].

Russia had few opportunities to reverse this trend. China's increased presence in the region was inevitable owing to China's economic potential and objective factors pushing it toward the West. Similarly, Central Asian republics did not have any alternative to collaboration with China. With the exception of Kazakhstan, Chinese funds are the principal source of invest- 
ments for the Central Asian republics, vital for political stability under conditions of weak institutions and tough international circumstances, including the withdrawal of American troops from Afghanistan and ISIS activity.

Guarantees from China that it will respect Russia's political interests in Central Asia are crucial for Russia. Such guarantees were secured as part of the joint statement signed in May 2015. Specifically, this statement confirms that "Parties ... will make coordinated efforts for mutual integration of EAEU and Silk Road Economic Belt building-up processes. They will coordinate the joint work in bilateral and multilateral formats, primarily, at the SCO meetings, taking a firm hold on the principles of transparency, mutual respect, equality of rights, the complementarity of different integration mechanisms and openness for all interested parties from Asia and Europe" [Kremlin, 2015].

Importantly, the statement does not resolve every issue between China and Russia. China's influence in Central Asia - and on EEU members - will inevitably increase. Both Kazakhstan and Kyrgyzstan still prefer to engage in bilateral dialogue with China. However, the very same claims are made against Russia, sometimes, for good reason - the joint statement itself was signed by Vladimir Putin and not by other EEU partners.

Furthermore, there remain contradictory understandings of the SREB's strategic agenda. While China is interested above all in extending its access to natural resources, Russia and Kazakhstan, on the contrary, want to develop high value-added production within their territories. China prefers infrastructure projects to be undertaken by Chinese companies and Chinese workers even while EEU members, notably Russia and Kazakhstan, are skeptical about their ability to attract a Chinese labour force and for that reason question the rationality of such terms. An additional issue is that of track gauges for railway projects. China prefers to use the European standard of 1,435 millimetres, while the track gauge on rail lines in the post-Soviet space is typically 1,520 millimetres.

Even while the document signed on 8 May 2015 does not resolve all of these contradictions, it does lay the foundations for developing compromises on outstanding issues. That said, much remains to be done.

Considerable efforts are needed to genuinely attract Chinese investments. At the end of 2015 and the beginning of 2016, Russia's media and expert community was heavily critical of Russia's turn to the East, and of the state of Russia-China relations. Trade turnover between the two countries decreased by almost 30\% in 2015 (although China's share in Russia's total turnover increased); Chinese investments in the Russian economy, regardless of stated intentions, were not made, and the substitution of European credits for Chinese credits did not spur Russian businesses [Korostikov, 2016]. Criticisms were certainly fuelled by the unrealistic expectations held by advocates of deepening of relations between Russia and China. Given Russia's recession and the impact of various sanctions, it was not feasible that efforts taken to attract foreign investments into the Russian Far East or to integrate the country into the Asia-Pacific region, would immediately bear fruit.

There are lessons to be learned from the political failures of 2015 in Asia. Political rapprochement with China does not change the fact that the Russian economy, given its current development model and the broader international climate, is a risky place to invest - China will not commit to a project at the expense of its commercial interests for the sake of geopolitical goals. In this context, the joint statement should not be interpreted as a guaranteed investment partnership between the two countries. Investments require conditions beyond political accords. However, the statement does illustrate that China is committed to an open SREB, and seeks to cooperate and coordinate investment strategies with Russia (and other countries) in central Eurasia. Russia now has an opportunity to benefit from regional development. The priority must be to clearly define those benefits. 


\section{The SREB and Opportunities for Russia}

The linkage of the SREB and EEU provides Russia with three major opportunities: integration into Eurasia's transport and logistics network, strengthened cross-border industrial cooperation and the potential emergence of a new centre of power in Greater Eurasia as regional integration deepens and widens.

With respect to integration into regional networks, the development of transit routes is the most obvious way to accomplish this. Currently, the most convenient and least costly route from China to Europe goes from Lianyungang to St. Petersburg (via Zhengzhou, Lanzhou, Urumqi, Khorgas, Almaty, Kyzylorda, Aktobe, Orenburg, Kazan, Nizhny Novgorod and Moscow) to access the Baltic Sea ports. A significant advantage of this route is that there are only two customs points: China-EEU and EEU-EU [Valdai Discussion Club, 2015].

However, the key benefits for Russia are not derived from the construction of the railway itself, especially if it is carried out by Chinese contractors and in accordance with Chinese standards. Rather, benefits derive from the establishment of modern logistics centres along the route that significantly decrease transport costs and thereby fuel competitiveness and the expansion of economic activity in cities along the route.

The second key transportation opportunity is the development of north-south transit corridors. These would supplement what is currently a primarily latitudinal transport infrastructure in the region and provide Russia with easier access to the growing markets of central and south Eurasia - north-western China, Uzbekistan, Afghanistan, Pakistan and India [Valdai Discussion Club, 2015]. It is likely that financing for such corridors would be provided by the AIIB or the Silk Road Fund.

The development of motorways between southern Ural and Siberia to Almaty, Tashkent and further into Afghanistan and Iran has triggered the emergence of an agrarian cluster in the south of Siberia. An international north-south transport corridor connecting Mumbai in India and the Iranian port of Bandar Abbas with Moscow and St. Petersburg (and potentially to Europe) is already in service, although still on a small scale.

In eastern Siberia, the railway connecting Kyzyl and Kuragino would be a promising north-south route if extended further south to Mongolia and western China. The integration of Russia's eastern territories into the regional logistics network is also possible via the SinoMongolian-Russian economic corridor [Makarov, Makarova, Karaganov et al., 2016]. In 2014, Chinese foreign affairs minister Wang Yi suggested this possibility, noting that it would support the integration of the OBOR with the Mongolian idea of "Steppe Road" and Russia's transEurasian corridor plans [Ministry of Foreign Affairs, 2015c].

Another way for Russia to integrate into the changing transport system of Eurasia is through the development of airline hubs. Increased levels of economic activity in the region and the growing number of flights between Asia and Europe warrant the construction of a major air communications centre in central Eurasia, potentially in Siberian cities such as Krasnoyarsk and Novosibirsk. The development of large-scale transport and logistics centres would boost the region's services sector and supplement the current industrial and scientific research specialization of these cities, making them significant centres of economic development.

Another opportunity for Russia from the SREB derives from the promise of increased transboundary industrial cooperation. For instance, cooperation between metallurgic plants in the Ural region and Kazakhstani mineral producers may be strengthened. Additionally, the preconditions for the recovery of the interregional Greater Altai project from the 1990s are in place, involving regions in Russia, China, Mongolia and Kazakhstan. There are also opportunities for cooperation in the Irtysh river basin where, under conditions of growing water deficits, 
decisions about water management and hydropower generation must be jointly taken. Prospects for cooperation among agro-industrial clusters in southern Ural, Siberia and northern Kazakhstan are high if the development of transport infrastructure can supply local producers with access to the major markets in the region [Valdai Discussion Club, 2015].

In the future, cooperation on industrial and transportation projects could develop into high-level integration processes [Karaganov, 2015; Bordachev, 2015]. The vast territory of greater Eurasia - from the ASEAN states and Korea in the east, India in the south and Transcaucasia in the west - represents a web of newly established transport, trade, investment, human and political ties. Within a new system of world trade where two mega-regional agreements - the Trans-Pacific Partnership and Transatlantic Trade and Investment Partnership - are playing a pivotal role, most states within greater Eurasia find themselves isolated and may turn to each other. The least developed among them, Afghanistan, Pakistan and the Central Asian republics, could reap significant benefits from rapid economic growth, as could Iran as it emerges from long years of sanctions. At the same time, the huge economies of India and China may serve as safety nets for a new co-development area.

The emergence of a fully integrated union similar to the EU is still unlikely in greater Eurasia - states are too dissimilar and attach high importance to their sovereignty. However, the emergence of a common economic space, including a free trade area and a unity of norms and standards, is a possibility.

The Shanghai Cooperation Organisation (SCO) may function as the core institution in an emergent greater Eurasia community. India and Pakistan joined the organization in 2015, countering the dominance of China. As a result, there may be greater opportunities to resolve regional problems. At the same time, members' efforts to extend the scope of SCO competence, initially to cultural and educational aspects and eventually to economic cooperation, are becoming more persuasive (Lukin, 2015]. This is a positive trend for the development of international cooperation within the SREB.

The idea of collaboration in greater Eurasia offers advantages to all its participants. It provides central Eurasian states with the resources necessary for economic development. In the case of China, collaboration advances its goal of "turning to the West." For India and Iran, prospects emerge from the intraregional division of labour. Russia benefits from the chance to rescue its economy from recession and can guarantee regional stability and participation in the development of Central Asia - a region that has always been a part of Moscow's core sphere of interest.

There is a long way to go before a greater Eurasia community emerges. First and foremost, the idea of EEU-SREB coordination specified in the joint statement of 8 May 2015 must be put into practice. As of now, it remains a concept rather than a complex of specific mechanisms to guide collaboration. Defining what exactly the EEU and Russia can offer to China should be one of the most important objectives of Russian foreign policy in the upcoming years.

\section{References}

Asian Development Bank (2015) ADB Annual Report 2014. Manila: Asian Development Bank. Available at: http://www.adb.org/documents/adb-annual-report-2014 (accessed October 2016).

Asian Infrastructure Investment Bank (2015a) Signing and Ratification Status of the AOA of the AIIB. Available at: http://euweb.aiib.org/html/aboutus/introduction/Membership/?show=0 (accessed October 2016).

Asian Infrastructure Investment Bank (2015b) Asian Infrastructure Investment Bank Articles of Agreement. Available at: http://euweb.aiib.org/uploadfile/2016/0202/20160202043950310.pdf http://www.aiib.org/uploa dfile/2015/0814/20150814022158430.pdf( accessed October 2016). 
Biriucov Eduard (2014) Role of IGC TRACECA in Regional Integration and Transit Cooperation. Presentation at the High-Level Thematic Roundtable at the 2nd United Nations Conference on Landlocked Developing Countries, Vienna, 4 November. Available at: http://www.lldc2conference.org/custom-content/ uploads/2014/11/Presentation_Vienna_2014_eng.pdf (accessed October 2016).

Bondaz A., F. Godement A. Kratz and R. Pantucci (2015) One Belt, One Road': China’s Great Leap Outward. June 2015. Asia Centre of European Council on Foreign Relations. Available at: http://www.ecfr.eu/page/-/ China_analysis_belt_road.pdf(accessed September 2015).

Bordachev Timofey (2015) Novoye yevraziystvo: Kak sdelat' sopryazheniye rabotayushchim. ("The New Eurasianism: How to Make a Pair.”) Russia in Global Affairs, 14 October. http://www.globalaffairs.ru/number/ Novoe-evraziistvo-17754 (accessed October 2016). (In Russian.)

Bordachev Timofey, Anastasia Likhacheva and Xin Zhang (2014) What Asia Wants, or the 'Four C's': Consumption, Connectivity, Capital and Creativity. Valdai Paper No. 1. Moscow: Valdai Club. Available at: http://valdaiclub.com/publications/valdai-papers/valdai_paper_1_what_asia_wants_or_the_four_c_s_ consumption_connectivity_capital_creativity/(accessed October 2016).

Chen Hongze (2015) Ekonomicheskiy poyas Shelkovogo puti i 'Morskoy shelkoviy put' 21-go veka' s tochki zreniya expertov KNR ("The 21st-Century Silk Road Economic Belt and Maritime Belt from the Perspective of China's Experts.”) Science and World 7(23). Available at: http://oaji.net/articles/2015/245-1439538260.pdf (accessed October 2016).

China Daily USA (2016) Full Text of Chinese President Xi Jinping's Address at AIIB Inauguration Ceremony. Available at: http://usa.chinadaily.com.cn/china/2016-01/16/content_23116822_2.htm (accessed October 2016).

Denisov Igor (2015) China Going West. Russia in Global Affairs, 19 March. Available at: http://eng.globalaffairs. $\mathrm{ru} /$ number/China-Going-West-17371 (accessed October 2016).

Fattibene D. (2015) Russia’s Pivot to Asia: Myths and Realities. Working Paper 15/44. Rome: Istituto Affari Internazionali.

Fedorenko V. (2015) The New Silk Road Initiative in Central Asia. Rethink Institute Working Paper (10). Available at: http://www.rethinkinstitute.org/wp-content/uploads/2013/11/Fedorenko-The-New-Silk-Road. pdf (accessed October 2016).

Gabuev A.T. (2015) Rossija i kitajskij proekt Jekonomicheskij pojas Shelkovogo puti. ("Russia and the Chinese Project of Silk Road Economic Belt.”) Vestnik APEC (1). (In Russian.)

Habova A. (2015) Silk Road Economic Belt: China’s Marshall Plan, Pivot to Eurasia or China's Way of Foreign Policy. KSI Transactions on Knowledge Society 8(1).

International Monetary Fund (2015) Regional Economic Outlook - Middle East and Central Asia, World Economic and Financial Surveys. Washington, D.C.: International Monetary Fund. Available at: https://www. imf.org/external/pubs/ft/reo/2015/mcd/eng/pdf/cca1015.pdf (accessed October 2015)

Karaganov S.A. (2015) Obeshhanie Evrazii: Povorot Kitaja na Zapad krajne vygoden Rossii. ("Promise of Eurasia: China's Turn to the West is Beneficial for Russia.”) Rossijskaja gazeta 6812 (241). (In Russian.)

Korostikov M. (2016) Uroki kitayskogo (“Chinese Lessons.”) Kommersant 8 February. Available at: http:// www.kommersant.ru/doc/2906658 (accessed October 2016). (In Russian.)

Kremlin (2015) Sovmestnoe zajavlenie Rossijskoj Federacii i Kitajskoj Narodnoj Respubliki o sotrudnichestve po soprjazheniju stroitel'stva Evrazijskogo jekonomicheskogo sojuza i Jekonomicheskogo pojasa Shelkovogo puti. ("Joint Statement on Cooperation on the Construction of Joint Eurasian Economic Union and the Silk Road Projects.”), 8 May. Available at: http://kremlin.ru/supplement/4971 (accessed October 2016). (In Russian.)

Larin A.G. (2015) Vozrozhdenie Kitaja i nekotorye voprosy rossijsko-kitajskogo sotrudnichestva. ("China's Resurgence and Issues of Russia-China Cooperation”) Kitaj v mirovoj i regional'noj politike. Istorija i sovremennost (China in World and Regional Politics: Past and Present) (20). (In Russian.)

Lukin A. V. (2015) SOC: v poiskah novoj roli. ("SCO: In Search of a New Role.”) In F. Lukyanov, ed., Mir na vzvode: pruzhina razzhimaetsja. (The World on Edge: The Spring Expands.) EKSMO, pp. 161-71. (In Russian.) 
Makarov I.A., E.A. Makarova, S.A. Karaganov, T.V. Bordachev, E.A. Kanaev, Ju.O. Litvinova, A.B. Lihacheva, A.S. Pestich, A.S. Pjatachkova, A.K. Sokolova, I.A. Stepanov and A.V. Shherbakova (2016). Povorot na Vostok. Razvitie Sibiri i Dal'nego Vostoka v uslovijah usilenija aziatskogo vektora vneshnej politiki Rossii (Turn to the East: The Development of Siberia and the Far East under the Intensification of Asian Vector of Russian Foreign Policy). Moscow: Mezhdunarodnye otnosheniya (International Relations). (In Russian.)

Ministry of Economic Development of the Russian Federation (2015) Ideja soprjazhenija proektov EAJeS i Jekonomicheskogo pojasa Shelkovogo puti. ("Idea of Joint Development of EAEU and Silk Road Economic Belt.”). Available at: http://economy.gov.ru/minec/press/interview/2015082704 (accessed October 2015).

Ministry of Economic Development of the Russian Federation (2016) Minister of Economic Development of the Russian Federation Alexey Ulyukaev is Appointed Executive Representing Russia in the Newly Created Asian Infrastructure Investment Bank, 16 January. Available at: http://economy.gov.ru/en/home/press/ news/2016180101 (accessed October 2016).

Ministry of Foreign Affairs of the People's Republic of China (2013) Xi Jinping: 'Promote Friendship Between Our People and Work Together to Build a Bright Future', 9 August. Available at: http://www.fmprc.gov.cn/ mfa_eng/wjdt_665385/zyjh_665391/t1078088.shtml (accessed October 2016).

Ministry of Foreign Affairs of the People's Republic of China (2015a) Foreign Ministry Spokesperson Hong Lei's Regular Press Conference on November 12, 2015. Available at: http://www.fmprc.gov.cn/mfa_eng/ xwfw_665399/s2510_665401/t1314306.shtml (accessed October 2016).

Ministry of Foreign Affairs of the People's Republic of China (2015b) Foreign Ministry Spokesperson Lu Kang's Regular Press Conference on December 29, 2015. Available at: http://www.fmprc.gov.cn/mfa_eng/ xwfw_665399/s2510_665401/t1328578.shtml (accessed October 2016).

Ministry of Foreign Affairs of the People's Republic of China (2015c) Wang Yi Meets with Lavrov on Global Issues, Cooperation, 8 April (video). Available at: http://www.fmprc.gov.cn/mfa_eng/sp/t1252887.shtml (accessed October 2016).

National Development and Reform Commission (2015) Vision and Actions on Jointly Building Silk Road Economic Belt and 21st-Century Maritime Silk Road. With the Ministry of Foreign Affairs, and Ministry of Commerce of the People's Republic of China, with State Council authorization. Available at: http://en.ndrc. gov.cn/newsrelease/201503/t20150330_669367.html (accessed October 2015).

NOVATEK (2015) NOVATEK zakljuchil ramochnoe soglashenie o priobretenii Fondom Shelkovogo Puti doli v Jamal SPG. ("NOVATEK Signed a Deal on Acquisition of a Share in 'Jamal LNG' by Silk Road Fund.") Press release, 3 September. Available at: http://www.novatek.ru/ru/press/releases/index.php?id_4=984 (accessed October 2016). (In Russian.)

Paris Costas (2015) Maersk Line CEO Calls for Container-Shipping Consolidation. Wall Street Journal, 9 October. Available at: http://www.wsj.com/articles/maersk-line-ceo-calls-for-container-shippingconsolidation-1444382176 (accessed October 2016).

Putin V. V. (2015) Interview to TASS and Xinhua News Agencies, 1 September. Available at: http://en.kremlin. ru/events/president/news/50207 (accessed October 2016).

Qu Xiaobo, and Qiang Meng (2012) The Economic Importance of the Straits of Malacca and Singapore: An Extreme-Scenario Analysis. Transportation Research Part E: Logistics and Transportation Review 48(1), pp. 258-65.

Russian Direct Investment Fund (2015) RDIF, Silk Road Fund and Vnesheconombank Finalize Cooperation Agreement. Press release, 3 September. Available at: http://rdif.ru/Eng_fullNews/1498 (accessed October 2016).

Russian Railways (2016) West Siberian Railway: The Road in Figures. Available at: http://zszd.rzd.ru/static/ public/ru?STRUCTURE_ID=60 (accessed March 2015).

Russian Federation Federal State Statistics Service (2016) Trade and services rendered to population. Available at: http://www.gks.ru/wps/wcm/connect/rosstat_main/rosstat/en/figures/trade/ (accessed October 2016)

Shajmergenov T. T. (2015) Jekonomicheskij pojas Shelkovogo puti: bol'shoj proekt, bol'shie voprosy. ("Silk Road Economic Belt: Big Project, Big Issues.”) Indeks bezopasnosti (Safety Index) (3). (In Russian.) 
Sisci F. (2015) One Belt, One Road. 17 July. Repubblica. Available at: http://temi.repubblica.it/limes-heartland/ one-belt-one-road/2070?refresh_ce (accessed October 2016).

Silk Road Fund (2015) The Silk Road Fund Teams Up with ChemChina to Invest in Pirelli. Available at: http://www.silkroadfund.com.cn/enweb/23809/23812/26968/index.html (accessed October 2016).

Shanghai Shipping Exchange (2016) Shanghai Containerized Freight Index. Available at: http://en.sse.net.cn/ indices/scfinew.jsp (accessed February 2015).

Ulyukaev A. V. (2016) Vystuplenie na inauguracionnom zasedanii Soveta upravljajushhih Aziatskogo banka infrastrukturnyh investicij (ABII). ("Speech at Inaugural Board Meeting of AIIB."), 16-17 January 2016, Beijing. (In Russian.)

United Nations Statistics Division (2016) UN COMTRADE. International Merchandise Trade Statistics, United Nations Statistics Division, New York, USA. Available at: http://comtrade.un.org/ (accessed October 2016)

Valdai Discussion Club (2015). Toward the Great Ocean - 3: Creating Central Russia. June. Moscow: Vaida Club. Available at: http://valdaiclub.com/publications/reports/toward_the_great_ocean_3_creating_central_ eurasia/ (accessed October 2016).

Vorob'ev V. J. (2014). "Novyj shelkovyj kurs: O kitajskoj idee postroenija «jekonomicheskogo prostranstva Velikogo shelkovogo puti. ("New Silk Course: About Chinese Idea of Silk Road Economic Belt.") Russia in Global Affairs (3). (In Russian.)

World Economic Forum (2015) What Can the New Silk Road Do for Global Trade? 22 September. Available at: https://www.weforum.org/agenda/2015/09/what-can-the-new-silk-road-do-for-global-trade/ (accessed October 2016).

Xi Jinping (2015) Keynote Speech During the Opening Ceremony of the Boao Forum for Asia (BFA) Annual Conference 2015 in Boao, South China's Hainan Province, March 28, 2015.

Zadorozhnyy A. (2016) Kak provalilsya 'povorot na Vostok'. ("How Has the 'Turn to the East' Failed.") 19 January. Znak. Available at: https://www.znak.com/2016-01-19/kitay_ne_spaset_putinomiku_i_ne_sobiralsya (accessed October 2016). (In Russian.) 